\title{
CORRELATION AND PATH ANALYSIS OF INTERACTION BETWEEN SNAP BEANS YIELD AND ITS COMPONENTS WITH CROP MANAGEMENT
}

\author{
N. Shaban* \\ Department of Agronomy, Faculty of Agriculture, University of Forestry, Sofia, Bulgaria
}

\begin{abstract}
PURPOSE: To assess the interaction between the applied some agronomic activities for the production of snap beans Phaseolus vulgaris cv. Starozagorski Cher using Path- correlation coefficient of analysis. METHODS: Using path analysis to illustrate real effect of minimizing doses of vegetative herbicide Basagran-200g/l (Bentazon-3-Isopropyl-1H-2,1,3-benzothiadiazin-4(3H)-one 2,2-dioxide) and Fusillade200g/l (Fluasifop-P-Butil-butyl 2-(4-\{[5-(trifluoromethyl)pyridin-2-yl]oxy\}phenoxy)propanoate) instead of using Dual 930EK/930g/l-s ( S-metachloras). Collecting data from long years, trials on plants treated with different combinations of foliar suspension fertilizer Lactofol ${ }^{\circledR}$ with pesticides. RESULTS: Growth rate RGR (mg g-1d-1) positively influenced by high statistical significance of the rate of net assimilation NAR- (mg.cm-2d-1). The correlation coefficient between the two indicators is $(r=0.692)$, followed by the dependence of RGR on the leaf area ratio LAR $\left(\mathrm{cm}^{2} \mathrm{mg}-1\right)$ with a value of $(\mathrm{r}=0.614)$. High statistical significance of correlation expressing the interaction between the leaf area ratio LAR ( $\left.\mathrm{cm}^{2} \mathrm{mg}-1\right)$ and root weight ratio RWR (g.g-1) $(\mathrm{r}=0.0 .837)$. Leaf area ratio LAR $\left(\mathrm{cm}^{2} \mathrm{mg}-1\right)$ has a relatively high positive correlation with the rate of net assimilation NAR- $(\mathrm{mg} . \mathrm{cm}-2 \mathrm{~d}-1)(\mathrm{r}=0.508)$. Results showed that fresh weight of pod/studied variant $(+++0.99)$, fresh weight of one pod $(+++0.77)$, fresh weight of pods/ plant $(+++0.67)$, calcium content in bean pods $(++0.57)$, pods number /plant $(++0.51)$, pollen fertility $(++0.44)$ had positive impact on yield. The partial function of the studied parameters on variability of bean yield is $98.9 \%$. Nitrate content had a major function to the yield (23.3\%) followed by Pods/ $\mathrm{kg}$ $(21.31 \%)$.Weeds manifestation caused most negative effect on yield (-0.64). CONCLUSIONS: This study reveals and identifies appropriate changes in applied agricultural techniques in the production of snap beans, which should be paid more attention to decrease water pollution caused by using the soilapplied herbicide without decreasing quantity and quality of yield.
\end{abstract}

Key words: Correlation, path-coefficient, snap bean, growth, yield.

\section{INTRODUCTION}

Production of vegetable crops has increased by $60 \%$ during the last twenty years. Especially in developing countries, this tendency related with needs healthy and fresh food. Vegetables cover 1.1 percent of the world's total agricultural area, with the region of Europe and Central Asia contributing with 12 percent of the total global area, and with 14 percent of global production (2010 data). Desire for yearround availability and increased diversity, and growing health awareness, have also been

\footnotetext{
*Correspondence to: Nidal SHABAN, Department of Agronomy, Faculty of Agriculture, University of Forestry in Sofia, St "kliment ohridski", 1797Sofia, Bulgaria, e-mail: shaban.nidal@gmail.com
}

important reasons for increased consumption of vegetables in these countries. (1) World production of snap bean is $\mathbf{2 4 , 7 5 2 , 6 7 5}$ tons /2018.(2) Green beans are dicotyledonous plants, and members of the family, Fabaceae, forming part of the species Phaseolus vulgaris. The snap bean originated from Peru, and spread to South and Central America by migrating Indian tribes. It was introduced to Europe by the Spanish explorers around the 16th century, and spread further throughout the world by Spanish and Portuguese traders. For a long time rare and expensive, this vegetable only became widespread in the 19th century. Nowadays the largest commercial producers of fresh green beans include the United States, 
China, Japan, Spain, Italy, and France. Snap beans are popular in many types of cuisines. Digestible, low in calories, and filled with vitamins, green beans are ideal for healthconscious weight watchers. (3)

Yield is a quantitative feature, which determined by the applied agricultural techniques. Their effect on yield, related to the interaction between them, is a useful indirect approach to improving yield. The value of the correlation coefficient varies from -1.0 to +1.0 . When the value of -1.0 indicates a complete negative relationship while the value of +1.00 indicates an ideal positive relationship. While the value of 0.00 represents a lack of correlation. Path analysis quantifies the relationships between the various components in their direct and indirect influence on grain yield. (4).

Correlation and path analysis has been used as a tool to generate information on the association of yield contributing treatments for the crop improvement program. Several authors studied the association of green pod yield with yield contributing traits in snap bean. For instance, (46) reported a positive correlation of pod number per plant with green pod yield in snap bean where as $(7,8)$ reported positive correlation of green pod length and green pod weight with green pod yield respectively. (4) Reported positive direct effects of green pod number per plant and single green pod weight on green pod yield per plant. Although several research results indicated the occurrence of strong association between green pod yield and yield contributing traits in snap bean.

Using of Path analysis to determine the independent variables in the construction of the production function allows identifying the interaction of certain indicators in the formation of the productivity of individual plants (9-11). The analysis of the yield from agricultural plants reveals and determines the relationships between them, and evaluates key indicators such as average and marginal coefficients of efficiency of elasticity and alternative variables of the production rate (12). The rate and dependence of the change in the volume of the studied factors forming the yield is an important advantage of the application of this statistical processing (13).

Study of fifty-eight genotypes of common bean (Phaseolus vulgaris L.) aimed to estimate the path coefficients between the primary and secondary characters on grain yield. The primary characters were set up by the number of seeds per pod (NSV), weight of one hundred grains (P100), number of pods per plant (NVP) and number of seeds per plant (NSP) and the secondary traits were number of days from germination to flowering (FL), number of days between emergence and harvest maturity (MC), plant height (EP), height of the first pod (PIV). The analysis of the path coefficient showed that the primary character with more direct effect on yield (PROD) was NVP (1.0011), associated with high correlation (0.754). Variables P100 and NSV showed high indirect effect on NVP of 0.8848 and 0.6369 , respectively. It was observed an increase in P100 and NVP in plants with short cycle and growing season and first pod height taller, and that the height of the first pod did not significantly influence productivity. (14)

Pod yield related with highly significant positive correlation with studied growth parameters $\quad(\mathrm{p}<0.05)$ except number of branches/ plant. Negative and significant correlation was observed between pod yield ha ${ }^{-}$ ${ }^{1}$ with the number of days to $50 \%$ flowering. Path analysis revealed that direct contributions of growth parameters were positive except leaf area index (LAI) and crop growth rate (CGR). The indirect contribution of characters through plant height and CGR were negative. The highest individual percentage contribution of growth parameter was from LAI (9.52), total dry weight (TDW) $(16.59,7.07,9.09)$ and combined mean, while the highest yield and yield component percentage contribution of 22.0, 29.28, 27.88 and 42.75 was from pod yield and the highest combined percentage contribution of $15.91,38.61,42.59$ and 25.14 was from number of pods per plant versus pod yield per plant. Plant height, leaf area index and total dry weight be selected for green bean improvement as these parameters if improved upon through breeding could increase pod yields of snap bean. (15)

Food safety can be ensured by reducing the use of pesticides in the production vegetable growth cycle. By means of field and laboratory experiments the antidote effect of the Lactofol (lactic acid salts, as a special product under the brand name Lactofol ${ }^{\circledR}$ turned out to be a stable form of chelates) against the negative effects of herbicides Basagran-200g/l (Bentazon) and Fusillade-200g/l (Fluasifop-P-Butil). on beans and peas plants was studied (20). The herbicides Bentazon and Fuzilad have a specific negative effect on the leaf gas-exchange in snap beans. A negative physiological aftereffect is observed in the young first-generation plants as well. The Lactofol, applied together with the herbicides Bentazon and Fuzilad, reduces this effect, and in most of the variants there occurs a stimulation of the processes. The different Lactofol forms, 
applied as antidotes of the herbicidal stress, cause a more stable gas-exchange - there occurs an activation of the photosynthesis, the transpiration, and the stomata conductance. No inhibition effect with respect to the contents of chlorophyll $\mathrm{a}$ and $\mathrm{b}$ in the green beans and peas leaves and the connected with it photosynthesis activity was recorded. The Lactofol $\mathrm{O}$ and Lactofol Fe forms are charcterized with the best physiological effect. The two crops are characterized with a different reaction (20).

\section{MATERIAL AND METHODS}

Data collected through long year's field trial with dwarf local snap bean cultivar Starozagorski Cher. Seeds were sown with the help of a trible with a distance of $30 \mathrm{~cm}$ between rows and $5 \mathrm{~cm}$ between plants. The experimental design adopted was RCBD (Randomized Complete Block Design) with four replications. All agronomic practices were kept uniform. Plants treated with different combinations of foliar suspensions fertilizer Lactofol ${ }^{\circledR}$ with pesticides (Table 1). At maturity, ten monitored plants were chosen from each replication for measuring the number of pods/plant, number of pods in kilogram snap bean, number of pods in variant, weight per pod $(\mathrm{g})$, number of flower/plant, plant height $(\mathrm{cm})$, pod length $(\mathrm{cm})$ leavesnomber/plant, index of pesticide injury, index of disease injury, polen fertility\% grain fresh weight $(\mathrm{FW})(\mathrm{g})$. Moreover, plant physiology was analyzed through three measurements of photosynthetic and transpiration intensity, and through analysis of photosynthetic pigments (chla, chlb and carotenoids), relative growth rate (RGR) net assimilation rate( NAR) leaf area rate (LAR), root weight rate( $\mathrm{RWR})$, leaf weight ratio (LWR). leaf gase exchange- rate of net phytosynthesis (A), transpiration intensity(E), stomatal conductivity (gs) by using LCA-4 (Analytical development company Ltd. Hoddesden England. Chemical composition of plants evaluated by testing the micro and macro nutrients contents. Weed density monitored and recorded as well during the consecutive experimental years.

Correlation coefficients calculated for fixing the degree of association of the different investigated parameters and snap bean yield as well as among themselves. Correlations calculated based on (16) and path coefficient analysis carried out as suggested by (17, 16, 18) and (19). Analysis done using AMOS Ver. 18 Software.

Table 1. Schem of using pesticides with different forms of suspension leaf fertilizer Lactofol ${ }^{\circledR}$ in snap bena production

\begin{tabular}{|c|c|}
\hline № & Variants \\
\hline 1 & $\mathbf{C}_{1}$ Control-non treated and non fertilized \\
\hline 2 & $\mathbf{C}_{2}$ Control - treated and fertilized \\
\hline 3 & $\mathbf{C}_{3} *$ Control using Lactofol ${ }^{(B)}$ O- 51/ha \\
\hline 4 & $\mathbf{C}_{4}$ Control using optimal dose of pesticides \\
\hline 5 & * Control using Lactofol $\mathrm{Fe}^{\circledR}-61 / \mathrm{ha}$ \\
\hline 6 & $* *$ Lactofol $\mathrm{Fe}^{\mathrm{B}}-61 / \mathrm{ha}+$ pesticides \\
\hline 7 & * Control using Lactofol $\mathrm{K} / \mathrm{Ca}^{\circledR}-41 / \mathrm{ha}$ \\
\hline 8 & ** Lactofol K/Ca ${ }^{(B)}-41 / h a+$ pesticides \\
\hline 9 & * Control using Lactofol $B^{\frac{1}{B}}-61 /$ ha \\
\hline 10 & ** Lactofol $\mathrm{B}^{\circledR}-61 / \mathrm{ha}+$ pesticides \\
\hline 11 & *** Lactofol $\mathrm{O}^{(\mathbb{R}}-5 \mathrm{l} / \mathrm{ha}+75 \%$ pesticides \\
\hline 12 & $* * *$ Lactofol $\mathrm{O}^{(\mathbb{R}}-51 / \mathrm{ha}+87.5 \%$ pesticides \\
\hline 13 & *** Lactofol $\mathrm{O}^{\mathbb{R}}-51 /$ ha+optimal dose of pesticides \\
\hline 14 & ** Lactofol $\mathrm{O}^{\circledR}-51 / \mathrm{ha}+75 \%$ pesticides \\
\hline 15 & ** Lactofol $\mathrm{O}^{\circledR}-5 \mathrm{l} / \mathrm{ha}+87.5 \%$ pesticides \\
\hline 16 & ** Lactofol $\mathrm{O}^{\circledR}-51 /$ ha+optimal dose of pesticides \\
\hline$\bullet$ & $\begin{array}{l}\text { * independently using of Lactofol } \\
* * \text { Mixed Lactofol with pesticides } \\
* * * \text { Lactofol then pesticides consistently } \\
\text { Variants 2-16 with optimal soil mineral fertilizing with NPK related with soil analysis }\end{array}$ \\
\hline
\end{tabular}




\section{RESULTS AND DISCUSSION}

The analysis of the results of the correlation coefficients of growth indicators of thirty-dayold snap bean plants from the obtained G1 seeds after treatment with combined application of lactofol and pesticides shows (Table 2) that the growth rate RGR $\left(\mathrm{mg} \mathrm{g}^{-1} \mathrm{~d}^{-1}\right)$ is positively influenced by high statistical significance of the rate of net assimilation NAR- $\quad\left(\mathrm{mg} . \mathrm{cm}^{-}{ }^{2} \mathrm{~d}^{-1}\right)$. The correlation coefficient between the two indicators is $(r=$
0.692), followed by the dependence of RGR on the leaf area ratio LAR $\left(\mathrm{cm}^{2} \mathrm{mg}^{-1}\right)$ with a value of $(r=0.614)$. With high statistical significance are the values of the correlations expressing the interaction between the leaf area ratio LAR $\left(\mathrm{cm}^{2} \mathrm{mg}^{-1}\right)$ and RWR - root weight ratio $\left(\mathrm{g} \cdot \mathrm{g}^{-1}\right)(\mathrm{r}=0.0 .837)$. The leaf area ratio LAR $\left(\mathrm{cm}^{2} \mathrm{mg}^{-1}\right)$ has a relatively high positive relationship with the rate of net assimilation NAR- $\left(\mathrm{mg} \cdot \mathrm{cm}^{-2} \mathrm{~d}^{-1}\right)(\mathrm{r}=0.508)$.

Table 2. Correlation coefficient of growth rate analyses of Phaseolus vulgaris L. after studied treatment

\begin{tabular}{|l|c|c|c|c|c|}
\hline & RGR & LAR & NAR & RWR & LWR \\
\hline RGR & 1 & 0.614 & $\mathbf{0 . 6 9 2}$ & $\mathbf{0 . 4 5 2}$ & 0.401 \\
\hline LAR & 0.614 & 1 & $\mathbf{0 . 5 0 8}$ & $\mathbf{0 . 8 3 7}$ & -0.041 \\
\hline NAR & $\mathbf{0 . 6 9 2}$ & $\mathbf{0 . 5 0 8}$ & 1 & $\mathbf{0 . 2 8 7}$ & -0.339 \\
\hline RWR & $\mathbf{0 . 4 5 2}$ & $\mathbf{0 . 8 3 7}$ & $\mathbf{0 . 2 8 7}$ & 1 & -0.011 \\
\hline LWR & 0.401 & -0.041 & -0.339 & -0.011 & 1 \\
\hline
\end{tabular}

RGR- Relative Growth Rate $\left(\mathrm{mg} \mathrm{g}^{-1} \mathrm{~d}^{-1}\right)$; LWR- Leaf weight rate(g.g $\left.\mathrm{g}^{-1}\right)$;

RWR- Root weight rate $\left(\mathrm{g} \cdot \mathrm{g}^{-1}\right) ; \mathrm{LAR}$ - Leaf area rate $\left(\mathrm{cm}^{2} \mathrm{mg}^{-1}\right)$;

$\mathrm{NAR}-\mathrm{Net}$ Assimilation rate $\left(\mathrm{mg} \cdot \mathrm{cm}^{-2} \mathrm{~d}^{-1}\right)$

The correlation analysis of the leaf gas exchange parameters in thirty-day-old snap bean plants from the obtained G1 seeds after treatment with combined application of lactofol and pesticides is with high statistical significance, an exception is the dependence of the rate of photosynthesis on the stomata conductivity (Table 3). These results may be related with experiments using Lactofol ${ }^{\circledR}$ (lactic acid salts, as special product under the brand name Lactofol ${ }^{\mathbb{B}}$ turned out to be a stable form of chelates) with antidote effect against negative effects of herbicides (Fuzilad and Bentazon) in field and laboratory experiments with beans and pea crops. Herbicides Bentazon and Fuzilad have a specific negative effect on the leaf gas-exchange in snap beans and peas.
A negative physiological aftereffect is observed in the young first-generation plants as well. Lactofol applied together with the herbicides Bentazon and Fuzilad, reduces this effect, and in most of the variants there occurs a stimulation of the processes. The different Lactofol forms, applied as antidotes of the herbicidal stress, cause a more stable gasexchange with activation of photosynthesis, transpiration, and stomata conductance. No inhibition effect with respect to the contents of chlorophyll $\mathrm{a}$ and $\mathrm{b}$ in snap beans leaves related with its photosynthesis activity was recorded. The Lactofol $\mathrm{O}^{\circledR}$ and Lactofol $\mathrm{Fe}^{\circledR}$ forms are characterized with the best physiological effect. (20).

Table 3. Correlation coefficients of the indicators of leaf gas exchange in thirty-day-old snap bean plants from the obtained G1 seeds after treatment with combined application of lactofol and pesticides.

\begin{tabular}{|l|c|c|c|c|}
\hline Parameters & A & E & gs & Ch.a+b \\
\hline Rate of net phytosynthesis (A) & 1 & 0.898 & 0.378 & 0.645 \\
\hline Transpiration intensity (E) & 0.898 & 1 & 0.711 & 0.794 \\
\hline Stomatal conductivity (gs) & 0.378 & 0.711 & 1 & 0.536 \\
\hline Chlorophyll a+b & 0.645 & 0.794 & 0.536 & 1 \\
\hline
\end{tabular}

Table 4. Correlation coefficients of the biometric parameters of leaf gas exchange in thirty-day-old snap bean plants from the obtained G1 seeds after treatment with combined application of lactofol and pesticides.

\begin{tabular}{|l|c|c|c|}
\hline Parameters & Plant height $(\mathrm{cm})$ & Root length $(\mathrm{cm})$ & Leaf area $(\mathrm{cm} 2)$ \\
\hline Plant height $(\mathrm{cm}$ & 1 & 0.776 & 0.705 \\
\hline Root length $(\mathrm{cm})$ & 0.776 & 1 & 0.824 \\
\hline Leaf area $(\mathrm{cm} 2)$ & 0.705 & 0.824 & 1 \\
\hline
\end{tabular}


The relationship between the biometric parameters of thirty-day-old snap bean plants from the obtained G1 seeds after treatment with combined application of lactofol ${ }^{\circledR}$ and pesticides strongly and positively proven (Table4). The correlation coefficient between fresh and dry biomass in snap bean plants after treatment with combined application of lactofol $^{\circledR}$ and pesticides is positive 0.919 .

Results showed that fresh weight of pod/ of studied variant $(+++0.99)$, fresh weight of one pod $(+++0.77)$, fresh weight of pods/ plant $(+++0.67)$, calcium content in bean pods $(++0.57)$, pods number /plant $(++0.51)$, pollen fertility $(++0.44)$ had positive impact on yield Figure B1.

Correlations between studied parameters in snap beans reveal well-defined patterns. A high significant positive correlation is observed between the height of the plants and the fruit set beans of one plant (++ 62), as well as between the height of plants and flowers of one plant (++ 0.53), proven with approved statistical significance. (Figure B1).

Weeds manifestation caused the most negative effect on yield (-0.69). Fresh weight of weeds caused a lower negative effect than their manifestation on snap bean yield (-0.48), the relationship between these two parameters of weeds in a snap bean field is the high positive correlation coefficient $(+++0.86)$. The negative effect of weed manifestation appears on some other studied parameters as catalase activity (-$0.58)$ and fresh weight of snap bean pods (-0.44 to -0.51$)$. The same effect of weeds manifestation appears on harvested pods number from on snap bean plant. Weeds manifestation inhibits plant height of snap bean plants with a high negative correlation coefficient (---0.67).

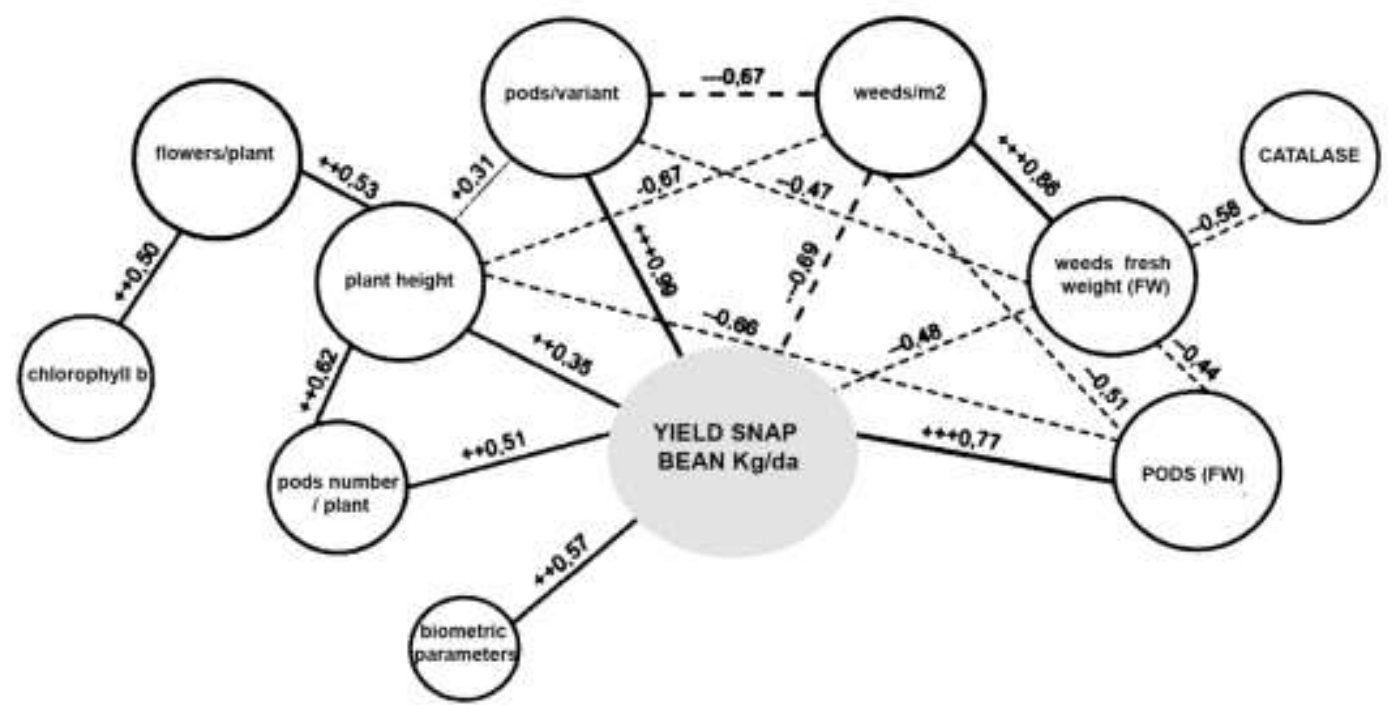

Legend

FIG B1

- Very strang positive relation $(+0.67+1.00)$ - Moderate to strong positive relation $(+0.34-0.66)$ Weak positive relation $(+0.00+0.33)$ - Moderate to stroeg negative relation $(-0.34-0.66)$ - Very strong negative relation $(-0.67 \quad-1.00)$

Figure B1. Correlation coefficient between yield and biometric parameters

Studied biometric parameters related with produced yield with positive correlation coefficient varied between (with plant height ++0.35 to harvested pods from treated variant+++0.99) (Figure B1).These data confirmed the tight relationship between yield and its structural components as mentioned by other authors $(14,15)$. Using pesticides in snap bean production caused a negative correlation coefficient on most studied parameters as pods length, the number of pods/plant decreased by almost 50\% in results of applied pesticides. Similar negative effects caused by disease (Figure B1a).

The correlation between the injuries caused by diseases of beans and plants height of (--54), to set flowers of one plant (--47), to content of chlorophyll "a" is moderately negative; (-0.42) as well as to content of total common 
plastid pigments "a" + "b" +"c" (--0.42)

(Figure B1a). Pesticide injuries to bean plants have a negative correlation with plant density $/ \mathrm{m}^{2}$ of snap bean $(-0.40)$, with a number of pods per plant (--0.54), with a length of the bean pods (--0.52), as well as with mass of bean pods (--0.41), proved with a relatively high degree of mathematical significance.

The multifunctional positive correlation between plant height with the number of bean pods per plant $(++66)$. Between pods of one plant and its flowers (++ 39), the flowers of one plant and total plastid pigments "a" + "b" + "C" (++ 0.34), between plastid pigments content and number of leaves of a plant (++ $0.58)$ proves differently manifested relation between factors of environment and specific biological requirements of snap beans during its vegetation period.

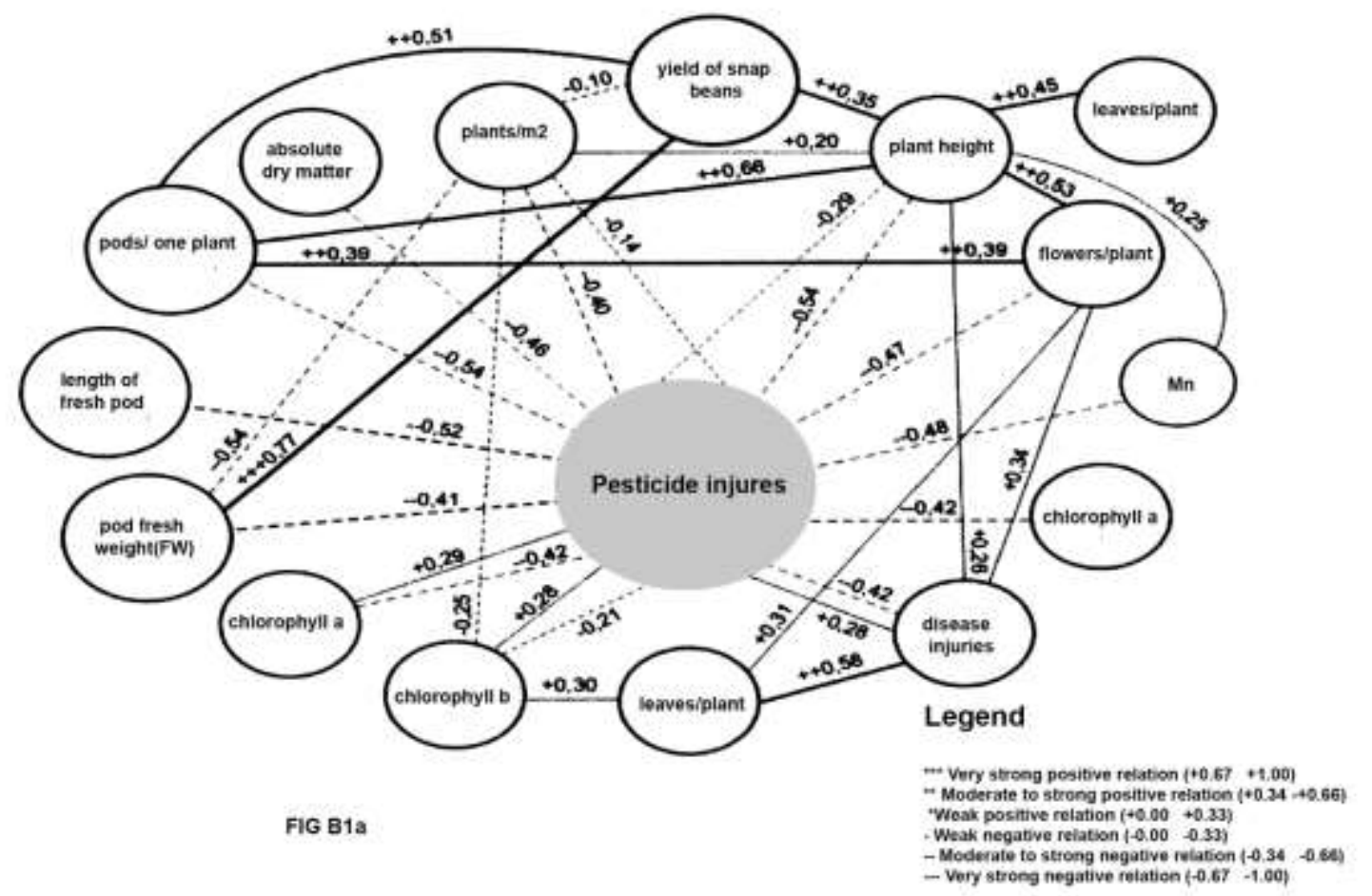

Figure B1a. Corelation coefficient between pest injuries and some parameters of snap bean

Studied physiological parameters as photosynthetic intensity, evapotranspiration, stomatal conductivity, pollen fertility caused high positive correlation coefficient with different values. (Figure B2). The positive correlation coefficient between the intensity of photosynthesis with stomatal conductivity $(+++0.88)$. The high correlation coefficient between stomatal conductivity and yield (++0.65). High correlation coefficient varied between studied physiological parameters. $(++0.63-+++0.88)$. The intensity of transpiration, rate of photosynthesis, stomata conductivity and fertility of pollen are interrelated. The values of the correlation dependence between them have a strongly proven positive sign (++ $0.63-+++0.88$ ).
These results follow logical tendency in plant growth process. A direct high positive effect of photosynthesis on the amount of yield has not been demonstrated $(+0.22)$.

Fertility of pollen related with strong positive correlation with physiological processes: with stomata conductivity $(+++0.88)$, with transpiration $(+++0.70)$, with intensity of photosynthesis $(++0.63)$. On the other hand, there is also a strong positive correlation between the intensity of photosynthesis and transpiration (+++ 0.67). These positive correlations have a good and very good degree of mathematical significance of the reliability of the experimental results. 


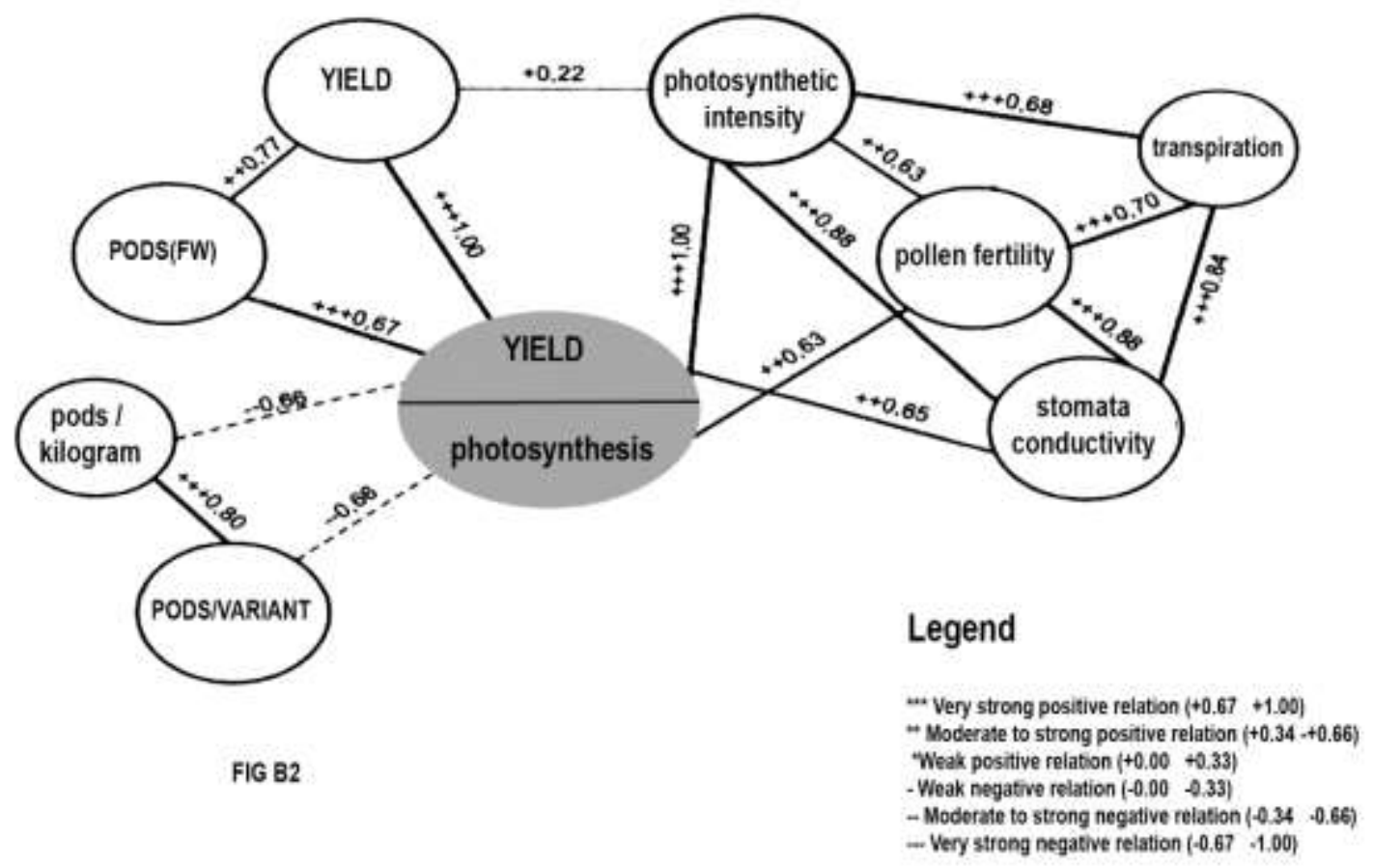

Figure B2. Correlation coefficient between yield and some physiological parameters of snap bean

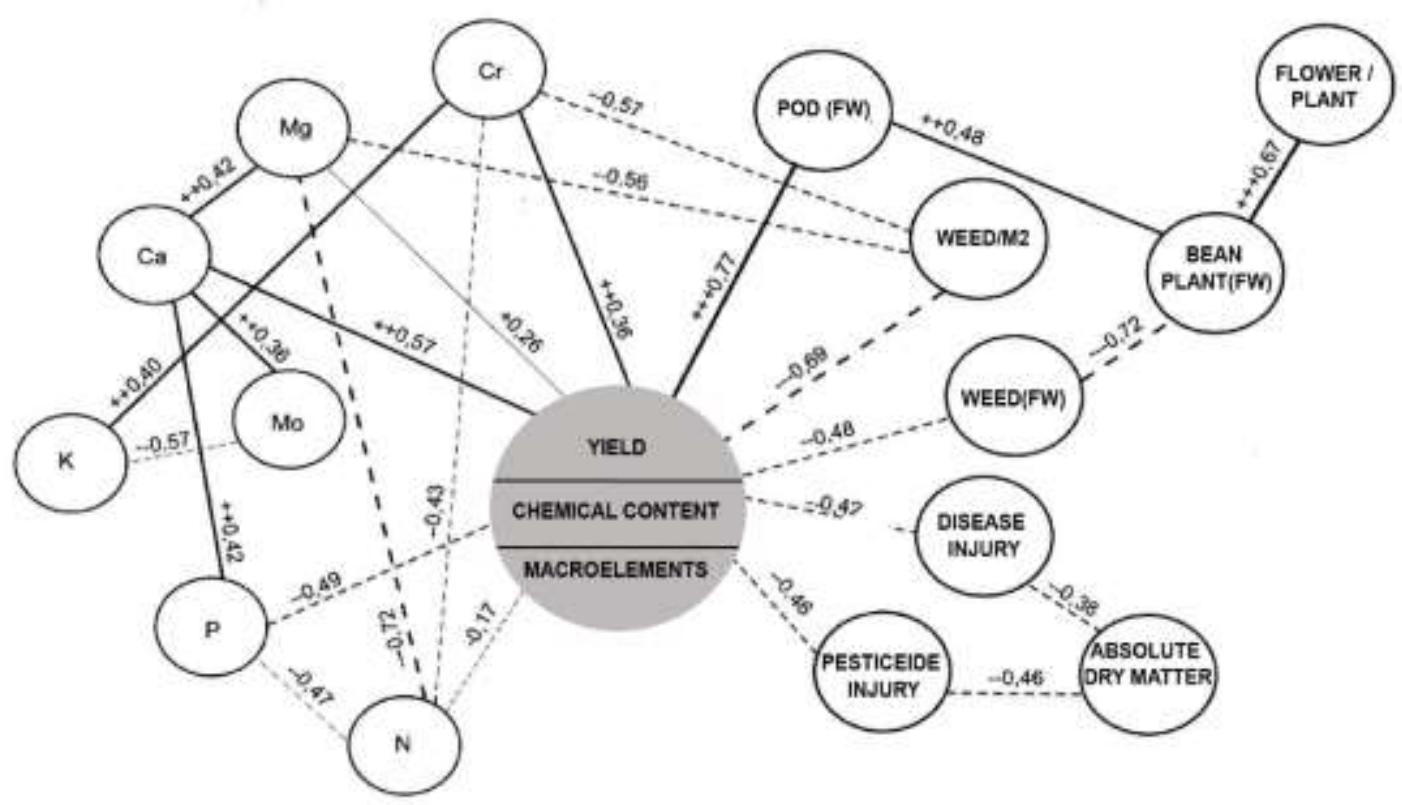

\section{Legend}

**. Very strong positive retation $(+0.67+1.00)$

- Moderate to strong positive retation $(+0.34+0.66)$

"Weak positive relation $(+0.00 \quad+0.33)$

FIG BS

- Whak negative retation $(-0.00-0.33)$

- Moderate to strong negative relation $(-0.34-0.66)$

- Very strong negative relation $(-0.67-1.00)$

Figure B3. Correlation coefficient between yield and some parameters of chemical contents with plant morphology of snap bean plants 
Strength manifested correlation coefficient between different macro and microelements varies from weak to moderate between them (Figure B3). Calcium snap bean pods content related with moderate positive relation with yield $(++0.57)$ followed by Chrome $(++0.36)$ and Molybdenum $(++0.26)$. With a negative correlation coefficient to the yield related Phosphorus (--0.49) followed by N (-0.17).
Significantly strong positive correlation dependence is established between the content of $\mathrm{N}$ and $\mathrm{Mn}(+++0.72)$ with a high degree of mathematical significance. Negative correlation dependence occurs between the content of $\mathrm{N}$ and Mo (--0.42), up to indicating a high degree of antagonism between these elements and their participation in the chemical composition of produced snap bean beans (Figure B4).

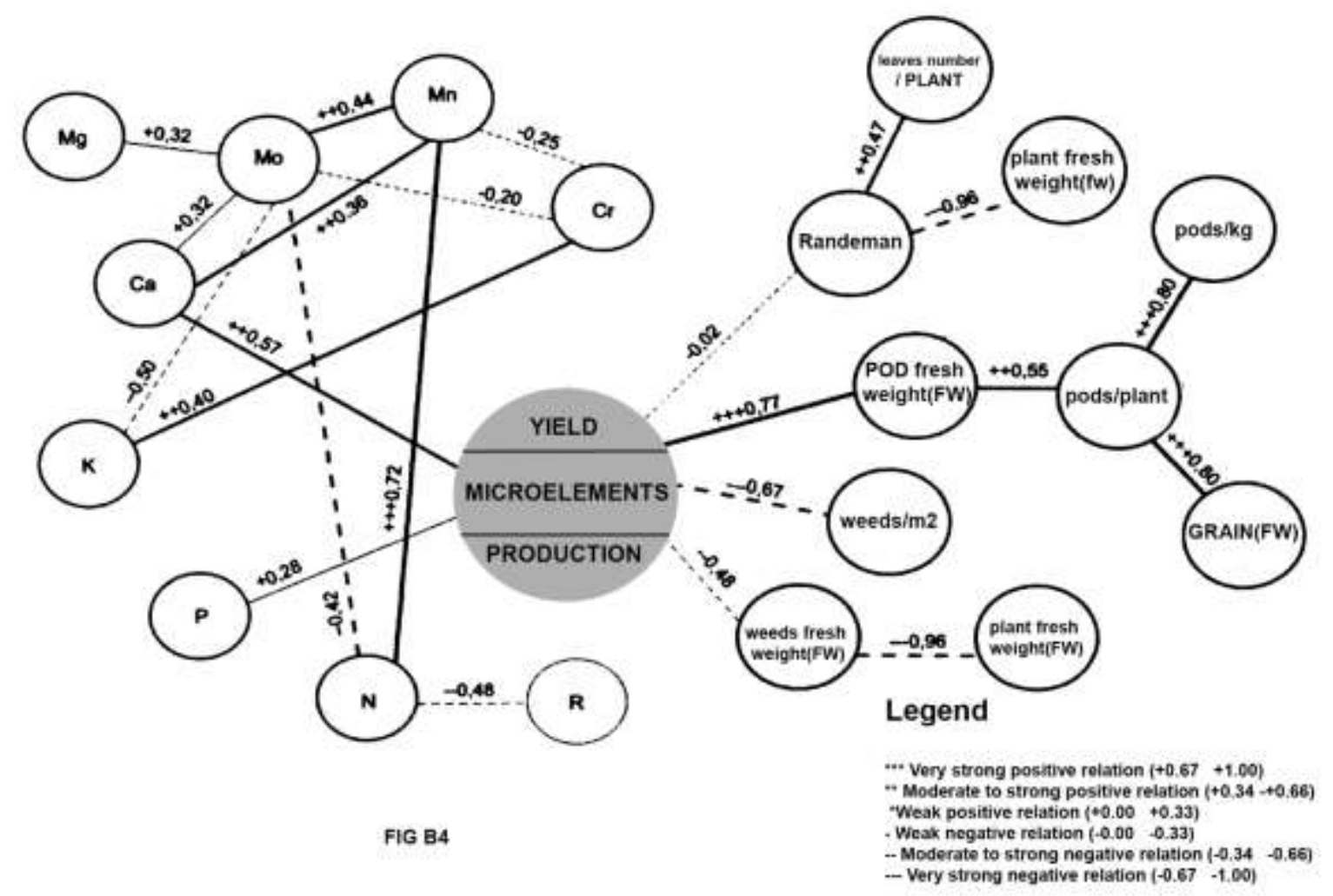

Figure B4. Correlation coefficient between yield, weed manifestation, macro and micro nutrient elements and some parameters of snap bean.

The strongest, positively manifested the correlation between transpiration and stomatal conductivity (+++ 0.80 ), followed by the relationship between peroxidase and catalase activity (+++ 0.76), between photosynthesis and transpiration, (+++ 0,68$)$ and the relationship between pollen fertility and transpiration (+++ 0.70), all of which have a very good and excellent degree of mathematical significance of the reliability of the experimental results (Figure B5).

The other correlations are also in a positive direction, although with a lower degree of mathematical significance. The most significant is the correlation between plastid pigment substances "a", "b" and "c" with chlorophyll "a" (+++ 0.87), followed by correlation between total plastid pigments and carotenoids "with" $(+++0.72)$ and between them and $\mathrm{Mn}(+++0.72)$. Other correlations with $\mathrm{Mg}, \mathrm{Mo}, \mathrm{N}$, and $\mathrm{Ca}$ had no mathematical significance.

The three-way correlation between chlorophyll "a" and chlorophyll "b" (++ 0.45), between chlorophyll "a" and carotenoids "c" (++ 0.40) and between carotenoids "c" is impressive and chlorophyll "b" (++ 0.60), characterized by relatively good mathematical significance of the experimental results.

The partial function of studied parameters on variability of bean yield is $98.9 \%$. Nitrate content had major function to the yield (23.3\%) followed by Pods/ $\mathrm{kg}(21.31 \%)$. 


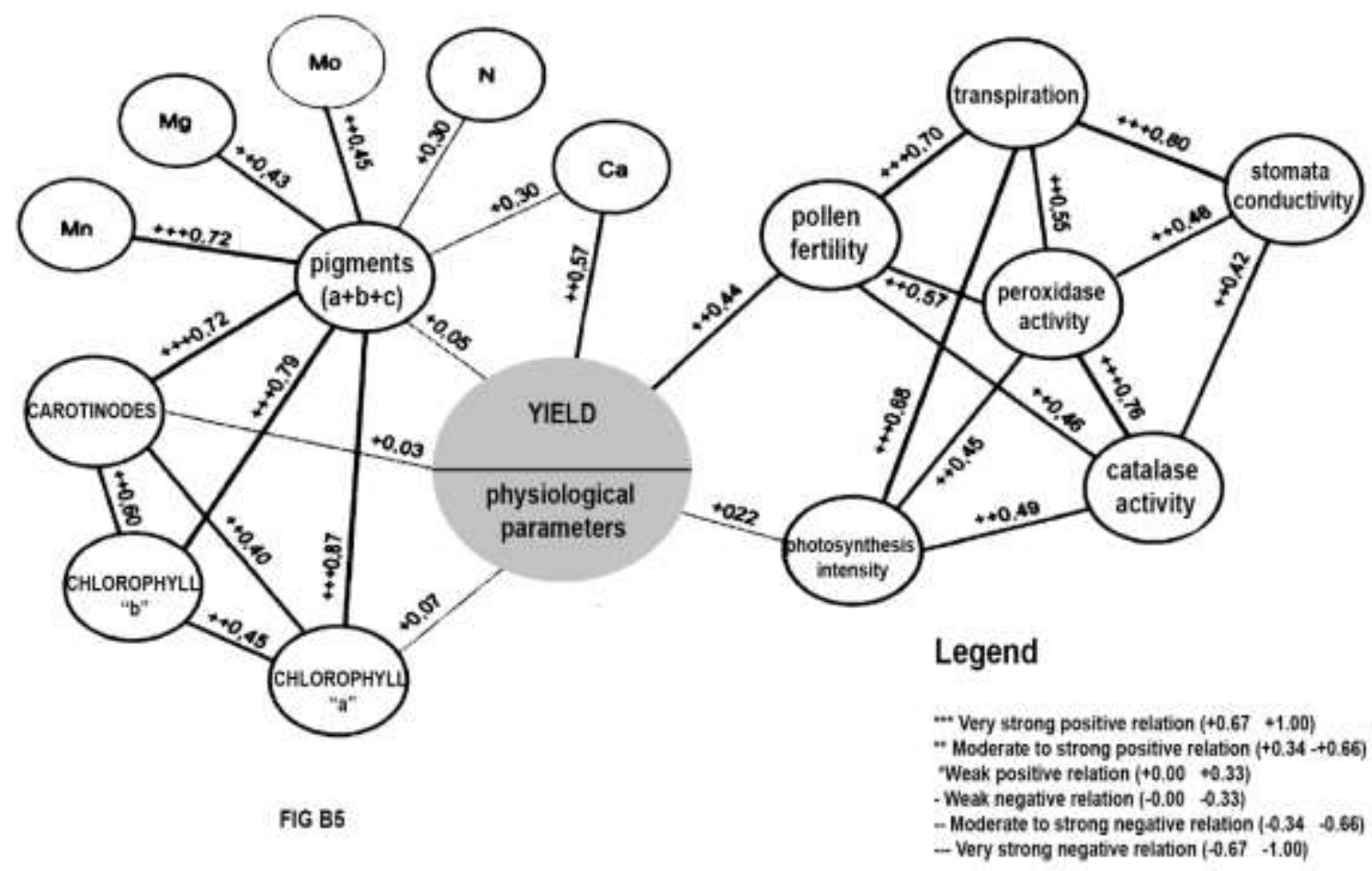

Figure B5. Correlation coefficient between yield, macro and micro nutrient elements and some parameters of snap bean

\section{Direct and indirect Path coefficients}

The applied research model of the direct and indirect Path coefficients proves that the number of bean pods (0.927), $\mathrm{NO}_{3}(0.970)$ and peroxidase activity $(0.861)$ have the strongest total positive effect on snap bean yield. The strong positive effect of bean number and peroxidase activity on yield is due to the positive total indirect effect through other traits. Direct effect of $\mathrm{NO}_{3}(1,290)$ on yield is the reason for the strong total positive effect. Significant total influence on bean yield was exerted by the biomass of dicotyledonous weeds (0.614), fresh weight of bean plants at harvest (0.589), fresh weight of beans (0.576), fresh weight of bean plants $(0.453)$ and the yield (0.429). For these features, the research model proves that their total indirect impact on yield through the other parameters determines their positive total influence.

The total effect on the yield of snap beans of the other studied traits is slightly negative. The relative share of the factors that have a positive influence on the formation of the yield of snap beans shows that the strongest total influence on the yield show: $\mathrm{NO}_{3}(23.3 \%)$ and the number of beans per kilogram $(21.3 \%)$ (Table 5).

Table 5. Relative participation of studied factors formulated yield of snap bean

\begin{tabular}{|l|l|l|}
\hline \multirow{2}{*}{$№$} & General variability of yield & 100.00 \\
\cline { 2 - 3 } & Partial function of studied parameters 98.9\%. from: & \\
\hline 1 & $\mathrm{NO}_{3}$ & 23.3 \\
\hline 2 & Pods/one kg & 21.3 \\
\hline 3 & Perpxcidase activity & 18.4 \\
\hline 4 & Fresh weight of dycotyledon weeds $(\mathrm{g})$ & 9.3 \\
\hline 5 & Freash weight of snap bean plant at harvesting $(\mathrm{g})$ & 8.6 \\
\hline 6 & Fresh weight of pods/ plant $(\mathrm{g})$ & 8.2 \\
\hline 7 & Fresh weight of bean plant after second treatment $(\mathrm{g})$ & 5.1 \\
\hline 8 & Randeman & 4.6 \\
\hline & Other factors & 1.1 \\
\hline
\end{tabular}


Direct and indirect interaction of weed manifestation on yield of snap bean show negative correlation coefficient with slight differences between dycotyledons and monocotyledons (Table 6)

Table 6. Direct\& indirect interaction of studied parameters on yield of snap bean

\begin{tabular}{|c|c|c|c|c|c|}
\hline \multirow[t]{2}{*}{ Parameters } & \multirow[t]{2}{*}{ № } & \multicolumn{2}{|c|}{$\begin{array}{l}\text { Direct\& indirect } \\
\text { interaction }\end{array}$} & \multirow{2}{*}{$\begin{array}{l}\text { General } \\
\text { indirect } \\
\text { influence }\end{array}$} & \multirow[t]{2}{*}{$\mathrm{R}$} \\
\hline & & $\mathrm{X}_{1}$ & $\mathrm{X}_{2}$ & & \\
\hline Fresh weight of dycotyledons weeds (g) & $\mathrm{x}_{1}$ & -0.443 & -0.221 & -0.221 & -0.664 \\
\hline Fresh weight of monocotyledons weeds (g) & $\mathrm{x}_{2}$ & -0.382 & -0.257 & -0.382 & -0.639 \\
\hline
\end{tabular}

This research gave valuable information about which steps of agro techniques needs more attention to enhance best quality and quantity of sustainable yield.

\section{CONCLUSION}

Path- analysis has more advantages in terms of assessment of the interaction between studied factors and their influences on the results than standard classical statistical methods. Production function analysis has advantages in the yield of agricultural crops because off, not only it allows establishing relationships between studied parameters, but also valued and key indicators such as average and marginal efficiency coefficient of elasticity and production rate alternative variables. It explores the dependence of rate of change in volume of the factors forming yield. Fresh weight of pod/studied variant high significant effect on snap bean yield (+++0.99), followed by fresh weight of one pod $(+++0.77)$, fresh weight of pods/ plant $(+++0.67)$, calcium content in bean pods $(++0.57)$, pods number /plant $(++0.51)$, pollen fertility $(++0.44)$ had a positive impact on the yield. The partial function of the studied parameters on the variability of bean yield is $98.9 \%$. Nitrate content had major function to the yield (23.3\%) followed by Pods/ $\mathrm{kg}$ (21.31\%). Weeds manifestation caused most negative effect on yield (-0.64) with slight differences between dycotyledons and monocotyledons ones. Growth rate RGR $\left(\mathrm{mg} \mathrm{g}^{-1} \mathrm{~d}^{-1}\right)$ positively influenced by high statistical significance of the rate of net assimilation NAR- $\left(\mathrm{mg} \cdot \mathrm{cm}^{-2} \mathrm{~d}^{-1}\right)$. The correlation coefficient between these two indicators was $(r=0.692)$, followed by the dependence of RGR on the leaf area ratio LAR $\left(\mathrm{cm}^{2} \mathrm{mg}^{-1}\right)$ with a value of $(\mathrm{r}=0.614)$. With high statistical significance are the values of the correlations expressing the interaction between the leaf area ratio LAR $\left(\mathrm{cm}^{2} \mathrm{mg}^{-1}\right)$ and RWR - root weight ratio $\left(\mathrm{g} \cdot \mathrm{g}^{-1}\right)(\mathrm{r}=0$.
0.837). The leaf area ratio LAR $\left(\mathrm{cm}^{2} \mathrm{mg}^{-1}\right)$ has a relatively high positive relationship with the rate of net assimilation NAR- $\left(\mathrm{mg} \cdot \mathrm{cm}^{-2} \mathrm{~d}^{-1}\right)(\mathrm{r}=$ 0.508).

The correlation analysis of the leaf gas exchange parameters in thirty-day-old snap bean plants from the obtained G1 seeds after treatment with combined application of lactofol and pesticides is with high statistical significance. An exception is the dependence of the rate of photosynthesis on the stomata conductivity. The correlation coefficient between fresh and dry biomass in treated plants from obtained G1 seeds with combined application of lactofol and pesticides is positive 0.919 .

This information determines which steps of agro techniques need more attention to enhance best quality and quantity of sustainable yield from snap bean.

\section{REFERENCES}

1. Bean-Production-Guideline-

2016.pdf.https://www.starkeayres.co.za/co m_variety_docs/

2. Green

Bean.https://en.wikipedia.org/wiki/Green_b ean

3. FAO Statistical Year book 2012.Europe and Central Asia Food and Agriculture

4. Shaban, N. 2005. Analysis of the correlation and regression coefficients of the interaction between yield and some parameters of snap beans plants.J. Sci. 3(6):27-31. 2005

5. Alemu Y., S. Alamirew \& Dessalegn L.2017. Correlation and Path Analysis of Green Pod Yield and Its Components in Snap Bean (Phaseolus Vulgaris L.) Genotypes. International Journal of Research in Agriculture and Forestry Volume 4, Issue 1, January 2017, PP 30-36 ISSN 2394-5907 (Print) \& ISSN 2394-5915 
(Online)

http://dx.doi.org/10.22259/ijraf.0401005. 2017

6. Dursun, A. 2007. Variability, heritablity and correlation study in bean (Phaseolus ulgaris L.) genotypes. J. Agri. Sci. 3 (1):1216. 2007

7. Pande, G.K., Seth, J.N. and Lal, S.D.1973. Variability and correlation studies in pole french bean in relation to green pod yield. J. The Punjab Horticultural, 23: 126-131. 1973

8. Shah, D., Pant, C.C. and Solanki, S.S. 1999.Studies on agronomic traits and genetic parameters in French bean (Phaseolus vulgaris L.). Progressive Horticulture, 31(3-4): 194-198. 1999

9. Jedynski S.2001. Heritability and path coefficient analysis of yield components in spring wheat. International journal of agriculture \& biology. 15608530/2004/06-1-138-142. 2001. http://www.ijab.org. 2001

10.Kashif M. and Khaliq I.2004 Heritability, Correlation and Path Coefficient Analysis for Some Metric Traits in Wheat. INTERNATIONAL JOURNAL OF AGRICULTURE \& BIOLOGY 15608530/2004/06-1-138-142.2004

http://www.ijab.org.2004

11.Narwal, N.K., P.K. Verma and M.S. Narwal, 1999. Genetic variability, correlation and path coefficient analysis in bread wheat in two climatic zones of Haryana. Agri. Sci. Digest Karnal, 19: 73-6 .1999

12.Nayeem K.A. and Baig K.S.2003 Correlation studies in durum wheat. J. Res. Angrau., 31: 116-21. 2003.

13.Steel, R.G.D and J.H. Torrie, 1984 Principles and Procedures of Statistics: A Biometrical Approach, second ed., McGraw Hill Book Co., New York 1984.

14.14.Pablo Diego Silva Cabral, Taís Cristina Bastos Soares, Andreia Barcelos Passos Lima, Yaska Janaína Bastos Soares e Josimar Aleixo da Silva. Revista Ciência
Agronômica, v. 42, n. 1, p. 132-138, janmar, 2011 Centro de Ciências Agrárias Universidade Federal do Ceará, Fortaleza, CE www.ccarevista.ufc.br Artigo Científico ISSN 1806-6690.2011

15.Dauda.S.N. Isa, A. S., E. Ndor ,E.D Azagaku and I. M. Haruna 2015 Correlation and Path Analysis of Yield,Growth and Yield Components of Green Bean (Phaseolus vulgarisL.) Varietes. PAT December,2015;11(2):8393ISSN: 0794-5213.2015

16. Singh R. K., Chaudhary B. D.Biometrical Methods in Quantitve Genetic Analysis. Rev.ed, pp318, Kalyani publishers, Ludhiana, New Dlhi. India. . 1985.

17. Dewey D. R and Lu K. M. Correlation and path coefficient analysis of components of crested wheat grass seed production. Agronomy J, 51:515-518. 1959

18.18.Soomro Z. A. Estimation of Gene Action and Selection Parameters in Quantitative and Qualitative Traits of Gossypium hirsutum L, Ph.D. Thesis , Sindh Agriculture University, Through Department of Plant Breeding and Genetics, Faculty of Crop Production, Tandojam.2010.

19.Arbuckle, J. L. Amos 18 user's guide. Chicago, IL: Amos Development Corporation. 2009

20.Stoeva N. and N. Shaban 2003 Influence of the Suspension Fertilizers Lactofol and Some Herbicides on Green Beans and Peas.II. Photosynthethic Activity and Plastid Pigments Contents.RASTENIEVUDNI NAUKI, 2003 Volume 40 Pages 52-57.2003

https://pubchem.ncbi.nlm.nih.gov/compound/F luazifop-P-butyl

http://www.cdms.net/ldat/ld3O1001.pdf

https://preparati.info/preparat/DUAL-GOLD930-EK/148

http://ecofol.com/technology/ 